\title{
Eğilme Etkisi Altındaki I Kirişlerde Yanal Yükün Taşıma Kapasitesine Etkisi
}

\author{
Sena GÜVEN (D) 1*, İlyas Devran ÇELIK (iD) \\ 1Süleyman Demirel Üniversitesi, Mühendislik Fakültesi, Isparta \\ Geliş Tarihi (Received): 11.03.2021, Kabul Tarihi (Accepted): 25.08.2021 \\ $\square$ Sorumlu Yazar (Corresponding author*): senaaguvenn@gmail.com \\ (C) +902462111200 且 +902462111072
}

\section{öz}

Taşıyıcı sistemlerde malzeme olarak yapısal çeliğin tercih edilmesinin sebeplerinden biri de yüksek dayanım ve sünek davranış sergilemesindendir. Çelik yapı elemanlarının şekil değiştirme kapasitesinin yüksek olması ve sünek davranış sergileyebiliyor olması uygun tasarıma bağlıdır. Fakat yapıya tasarım dışı yük gelmesi, çelik yapı elemanlarının taşıma kapasitesinin aşılması halinde, stabilite problemlerine neden olmaktadır. Bu durum özellikle çelik yapılarda kirişlerin kuvvetli eksen tarafında eğilme etkisi altında iken yanal yük alması şeklinde gözlenir. Bu stabilite problemi önlenmez ise sistem plastik deformasyona maruz kalıp göçme durumuna geçerek yanal olarak burkulacaktır. Bu durumda, yüksek süneklik özelliklerine sahip çelik taşıyıcı sistemin gevrek davranış göstermesinin önünü açacaktır. Bu araştırma makalesi, eğilme etkisi altında bulanan I kirişte yanal yükün kiriş kapasitesine etkisini incelemek amacıyla yapılmıştır. Çalışmada farklı yüklerin etkisi altında bırakılan, farklı kesit ve açıklıklarda kirişler kullanılmıştır. Bu bağlamda, yanal yükün kiriş kapasitesine etkisinin ortaya koyulması amacıyla Ansys Workbench sonlu elemanlar programında 19 farklı modelin 11 farklı artan yük altında analizleri yapılmış ve elde edilen sonuçlar karşılaştırmalı olarak sunulmuştur.

Anahtar Kelimeler: Ansys workbench, çelik kirişler, plastik şekil değiştirme, taşıma kapasitesi, yanal yük

\section{Effect of Lateral Load on the Carrying Capacity of I Beams under Bending Effect}

\begin{abstract}
One of the reasons that steel is preferred for carrier system material is due to its high strength and ductile behaviour. Deformation capacity and the ductile behaviour of steel structure components depends on a suitable design. However, steel structure components may face stability problems due to being exposed to high out-of-design loads. For steel structures, this condition can be observed while beams of the steel structure is under bending effect on their strong axis and is also exposed to lateral loading. If this stability condition is not prevented, the system will undergo plastic deformation into a failure state and lateral buckling will occur. Mentioned condition may cause the steel carrier system with high ductility properties to display brittle behaviour. In this research paper, the effect of lateral load on the capacity of a I beams under bending effect is investigated. In the study, beams with different section and span properties are exposed to different loads. In this context, in order to determine the effect of lateral load on the capacity, 19 different models with 11 different loads on each model are analysed using Ansys Workbench finite element program and the results are presented comparatively.
\end{abstract}

Keywords: Ansys workbench, steel beams, plastic strain, carrying capacity, lateral load 


\section{GíRiş}

Çelik malzeme olarak yüksek şekil değiştirme ve dayanım kapasitesine sahip bir malzemedir. Ancak çeliğin bu niteliğini yapı performansına yansıtabilmesi için sistem geometrisine, yapı elemanı kesit özelliklerine ve birleşim detaylarına dikkat edilmesi, özellikle gevrek kırılmaya neden olabilecek tasarımların önüne geçilmesi gerekir.

Çelik kirişler, yer aldığı sistemler içerisinde döşemelerden aldıkları sabit (ölü) ve hareketli yükleri mesnetli oldukları kolon ve perdelere aktaran taşıyıcı yapı elemanlarıdır. Üzerlerine etki eden bu yükler nedeniyle eğilme momenti ve kesme kuvvetleri meydana gelir. $\mathrm{Bu}$ sebeple çelik kirişlerde deformasyonlar oluşur. Bahsedilen bu eğilme şekil değiştirmeleri kiriş tasarımında dikkate alınması gereken unsurlardan biridir. Şekil 1'de eğilme etkisi altındaki çelik bir kirişin genel davranışı verilmiştir (Ayhan, 2007).

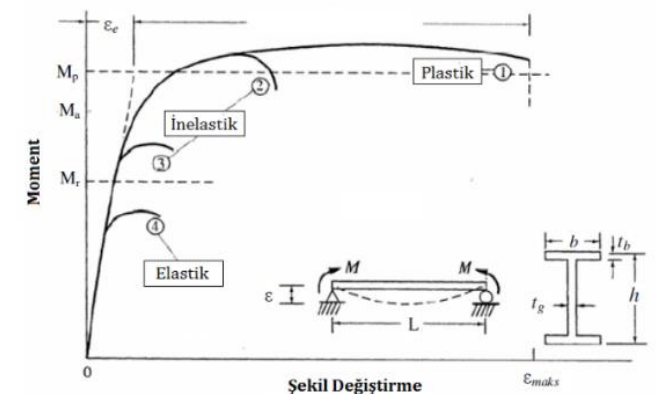

Şekil 1. Kirişin eğilme altındaki genel davranışı (Ayhan, 2007)

Kirişlere düşey yük veya eğilme momenti uygulandığında yük kritik değerin altında kaldığı sürece sadece düşey yer değiştirmeler oluşur ve kesit gövdesi stabilitesini korur. Uygulanan yük yanal stabilite açısından kritik değeri aştığında ise kirişin düzleminden saptığı ve stabilitesini kaybettiği görülür. Bu stabilite kaybı yanal burkulma olarak adlandırılır. Bu duruma neden olan kritik yüke de kritik yanal burkulma yükü denir. Şekil 2'de çelik bir kirişin eğilme etkisi altında yanal burkulma haline ait genel bir görünümüne örnek verilmiştir.

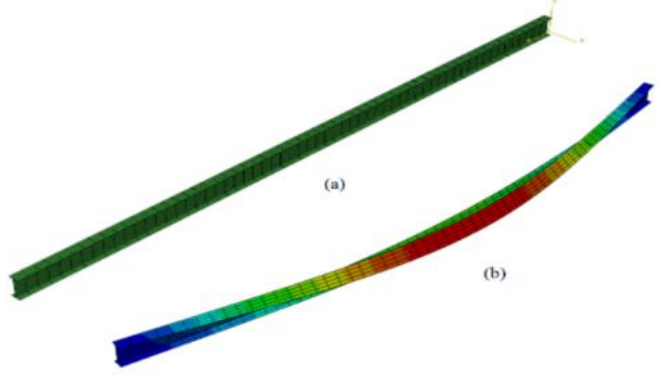

Şekil 1. Çelik kirişin burkulma haline ait genel görünüm (Yılmaz ve Kıraç, 2016)

Sürekli bir döşeme sisteminde döşeme ortasına gelen ana ve ara kirişler birlikte çalıştığı taşıyıcı sistem elemanları sayesinde yanal tutulma koşullarını çoğunlukla sağlamaktadırlar. Ancak, döşeme kenarında konumlanan cephe kirişleri için bir yönde tutulma koşulları sağlanırken diğer yönde serbestlik ortaya çıkmaktadır. Bu durum ile özellikle çelik endüstri yapılarında cephe kirişi olarak konumlandırılan yapı elemanlarında; kren yüklerine, oluk yüklerine ve sundurma yapılarında çekme halatlarının bağlantı noktasına hizmet veren kirişlerde karşılaşılmaktadır. Cephe kirişleri yapıdan gelen döşeme vb. yüklerle eğilme etkisi altında iken bu hizmet altında ek olarak kiriş gövdesinden bu gibi yanal yüklere de maruz kalmaktadır. Kiriş gövdesinde yanal stabilite açısından sorunlar ortaya çıkabilmektedir.

Eğilme etkisi altındaki çelik kirişlerin taşıma kapasitesi ve sünekliğinin belirlenmesinde rol oynayan burkulma haline geçmesini tetikleyecek durumlar tasarımda dikkate alınmalıdır. Fakat bazen kirişlerde yanal tutulma sağlanmasına, sistem içerisindeki kesiti ve sınır koşullarının uygun olmasına rağmen kiriş aldığı yükle birlikte kapasitesinin aşılmasından dolayı bu yanal harekete maruz kalabilmektedir.

Endüstri yapılarında tasarım aşaması sonrasında hizmet verdiği amaç doğrultusunda ilave yapıların mevcut tasarıma eklenmesi olası intimaller arasındadır. Bunlardan en önemlisi genellikle yapılarda kullanılan konsol olarak çalışan sundurma yapılarıdır. Sundurma kaynaklı taşıyıcı sistemin ana yapıyla ilişkisi genellikle cephe kirişleri üzerinden sağlanmaktadır. Yapılan bu ilave yapılar tasarım sırasında dikkate alınmadığından dolayı cephe kirişleri tasarım yüklerine ek olarak ilave yüklere maruz kalabilmektedir. Bu yüklerde cephe kirişlerine ilave eğilme momentleri etki etmektedir. Şekil 3 'te yapıya sonradan eklenen sundurma yapısına ait bir örnek gösterilmiştir. Şekilde gösterilen bu yapıda sundurma yapısı tasarım sonrası yapılmış olup ilk aşamada bir sorun teşkil etmiyor gibi gözükse de zaman 
içerisinde bu yapıya gelen kar yükü vb. olası yüklerden cephe kirişinin kapasitesini aşarak yanal burkulmasına sebebiyet verebilmektedir.
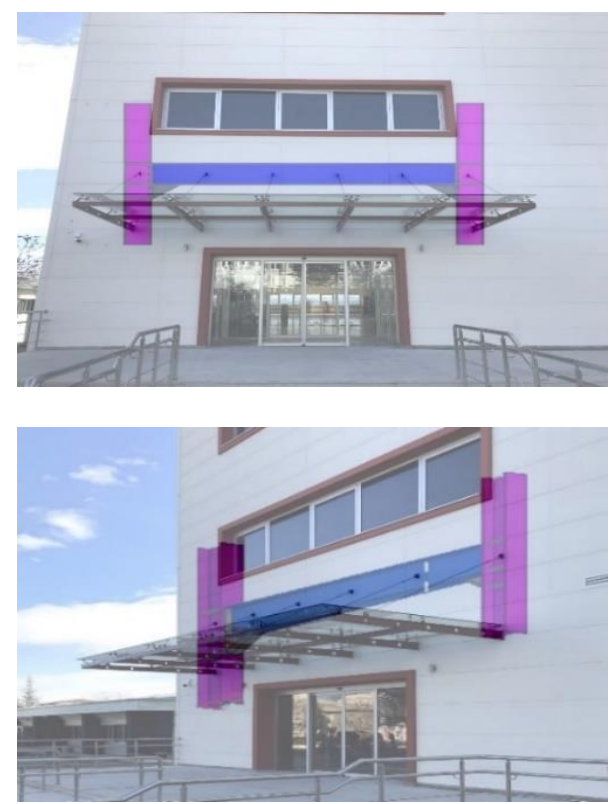

Şekil 3. Sundurma yapısına ait örnek görünüm

Bu bilgiler ışığında yapılan bu çalışmada; tasarım şartlarını sağlayan, çerçeve sistem içerisinde hizmet veren çelik kirişin, servis ömrü içerisinde yapılan değişikliklerden kaynaklanan ve başlangıçta dikkate alınmayan ilave yüklere maruz kalması durumunda, stabilitesini kaybederek yanal burkulma haline geçmesi, bu durumda etkili olan ilave yanal yüklerin kapasite üzerindeki etkisi incelenmiştir. Çalışmada; mesnet koşulları sınırlandırılmış farklı açıklıklardaki, farklı boyutlarda tasarlanan çelik kirişler, değişen yanal yük kaynaklı gövdeye etkiyen ilave burulma momentleri altında analiz edilmiştir. Analizlerde Ansys Workbench programı kullanılarak deplasman kontrollü yükleme yapılmıştır. Bu kapsamda; yanal burulma momentlerinin kiriş taşıma kapasitesi üzerine etkisi sayısal olarak incelenmiştir.

Literatürde; kirişin yanal burkulmasına karşın yapılan araştırmalarda kirişlerin kesit özellikleri, sınır koşulları ve yükleme durumu parametrelerine bağlı olarak birçok deneysel ve sayısal analizler yapılmıştır. Analizlerde sonlu elemanlar yöntemleri kullanılmıştır.

Attard (1986), ince cidarlı ve açık kesitli kirişıerin yanal burulmalı burkulma yükünün hesaplanması için kirişlere statik yükleme yapıp iki yeni sonlu eleman formülasyonunu ortaya koymuştur. Ortaya koyduğu iki formülasyonun da deneysel olarak belirlenmiş sonuçlarla doğru olduğu teyit etmiştir.
Mahendran ve Avery (1996), çalışmalarında içi boş üçgen başlığa sahip I profillerinin eğilme davranışlarını incelemek amacıyla sonlu eleman analizleri ve büyük ölçekli deneyler gerçekleştirmişlerdir. Gövdeye eklenen berkitme levhalarının kalınlık ve sıklıklarına bağlı olarak eğilme momenti taşıma kapasitesinin arttığını ve buna bağlı olarak yanal burkulma değerinin azaldığını belirlemişlerdir.

Lee ve ark. (2002), çalışmalarında çeşitli yüklemelere maruz kalan I kesitli kompozit kirişin yanal burkulmasını inceleyebilmek için analitik bir model oluşturmuşlardır. Uygulanan yükün yerinin burkulma kapasitesi üzerinde etkileri de analizlere dahil edilmiştir.

Moon ve ark. (2009) oluklu gövdeli I kesitli kirişlerin eğilme etkisi altındaki yanal burulmalı burkulma mukavemetinin hesaplanması için bir yöntem önermişlerdir. Kirişlerin analizlerini sonlu eleman yöntemi kullanılarak yapılmış ve önerilen yöntem sayesinde yanal burulmalı burkulma mukavemeti doğrulanmıştır. Çalışmalarının sonucunda oluklu gövdeli I kesitli kirişlerin eğilme sabitinin düz gövdeli I kesitli kirişlerden daha büyük olduğunu tespit etmişlerdir.

Tsavdradis ve Mello (2011) dairesel açıklıklı çelik kirişlerde gövde burkulması ve yük kapasitesini incemelek amacıyla 7 numune oluşturulup test edilmiş ve 14 sayısal test numunesi geliştirmişlerdir. Sonlu elemanlar yöntemi ile analiz ederek sonuçları tam ölçekli deneylerle karşılaştırmışlardır.

Ellabody (2011), yanal burulma ve distorsiyonel burkulma modları altına normal ve yüksek mukavemetli çelik petek kirişlerin davranışlarını incelemiştir. Kirişlerin analizi için sonlu eleman modeli oluşturmuştur. Kesit geometrilerindeki değişimin etkilerini incelemek için sonlu elemanlar modeli kullanılarak kapsamlı bir parametrik çalışma gerçekleştirilmiştir. Ellabody yaptığı parametrik çalışmada, gövdedeki burkulma ince cidarlı petek kirişlerin göçme yükünde önemli bir azalmaya neden olduğunu ele almıştır. Ayrıca, yüksek mukavemetli çelik kullanımının, daha ince cidarlı petek kirişlerin kırılma yüklerinde önemli bir artış sağladığı da görülmüştür.

Trahair (2016), yaptığı çalışmada düzgün yayılı yükle yüklenen ve basit mesnetlenen çift simetrik kirişlerin elastik yanal burkulmasını analiz etmek için dört farklı yöntem kullanmıştır. Bu dört farklı yöntemden ikisi, sonlu integral yöntemine dayalı bir bilgisayar programı kullanılarak veya el ile hesaplamaları yapılarak diferansiyel denklemleri sayısal olarak çözer. Dört farklı yöntem içeren bu çalışmanın sonuçlarında birbirine 
yakın değerler oluşturduğu gözlemlemiş ve daha önce kullanılan diferansiyel burulma denklemlerinin hatalı olduğu sonucuna varmıştır.

Mudenda ve Zingoni (2018), çalışmalarında açıklıkları ve yükseklikleri çeşitli kılarak tek ve çift simetrik başlıklı sıcak haddelenmiş çelik kirişlerde yanal burulma davranışını incelemek amacıyla analizlerde ABAQUS yazılımını kullanmışlardır. Çalışmalarının sonucunda üst başlık destekli tek simetrik kirişlerde dikme yüksekliği arttıkça kritik burkulma momentinin arttığı fakat kiriş açıklığının artması kritik burkulma momentini azalttığı gözlemlenmiştir.

Yapılan çalışmalarda, eğilme etkisi altında, yükleme durumuna ve sınır koşullarına bağlı olarak statik yükleme analizleri yapılmıştır. Bu çalışmaların sonucunda kiriş açıklığı, gövde yüksekliği, cidar kalınlığı ve yükleme noktasının kirişin yanal burkulma davranışı üzerindeki etkileri belirlenmeye çalışılmıştır. Eğilme altındaki kirişlerde olası burkulma durumları, deneysel ve sayısal çalışmalarda gövde rijitleştirme levhaları, sayısal modellerde yay sabitleri kullanılarak kontrol altında tutulmaya çalışılmıştır.

\section{MATERYAL VE YÖNTEM}

Bu çalışma, eğilme etkisi altında kalan çelik kirişlerde; yanal yükün taşıma kapasitesine etkisini değerlendirebilmek adına doğrusal olmayan sonlu elemanlar yöntemi kullanılarak farklı yükler ve farklı açıklıklar için yapılan sayısal analizleri kapsamaktadır. Sayısal olarak yapılan analizlerde; kiriş açıklığı, kiriş kesit ve yük değerleri boyutsal parametreler olarak alınmıştır. Analizlerde Ansys Workbench Sonlu Elemanlar programı kullanılmış ve yapısal çelik malzeme özellikleri S235 olarak programa tanıtılmıştır.

Analizlerde, çerçeve bir sistem içerisinde çalışan sürekli bir kiriş davranışı elde etmek amacı ile kirişler koIonlara her iki uçtan moment aktaracak şekilde mesnetlenmiştir. Şekil 4'te analizlerde kullanılan sayısal modellerin genel görünümü ve bu genel görünüme ait boyutsal değişkenler gösterilmiştir.

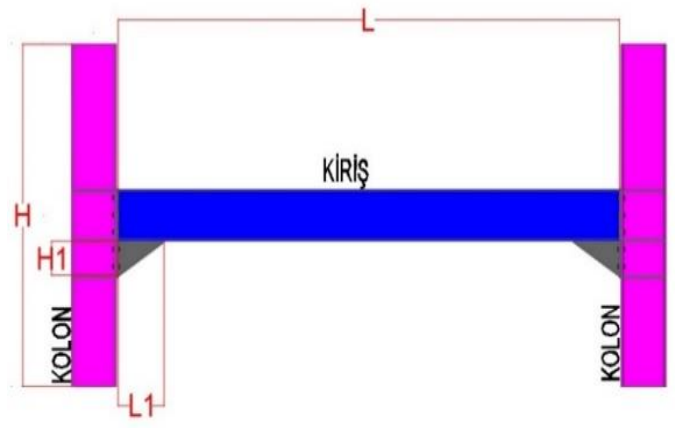

Şekil 4. Sayısal modelin boyutsal parametrelerine ait genel görünüm

Analizlerde kiriş açıklığı ve kesiti değişken olarak alınırken, farklı yükleme durumları için bir kıyas düzlemi yakalayabilmek için kolon yüksekliği $3 \mathrm{~m}$ olarak tasarlanmış ve kesiti sabit tutulmuştur. Kiriş kesitleri için 3 farklı HEA ve IPE profilleri kullanılmış, kiriş açıklıkları $6 \mathrm{~m}, 8 \mathrm{~m}, 10 \mathrm{~m}$ ve $12 \mathrm{~m}$ olmak üzere toplamda 19 farklı sayısal model oluşturulmuştur. Analizlerde kullanılan modellerin boyutsal parametrelere ait değişkenleri Tablo 1'de verilmiştir.

Tablo 1. Modellere ait boyutsal parametreler

\begin{tabular}{|c|c|c|c|c|c|c|}
\hline Model & Kolon & Kiriş & $\mathrm{H}(\mathrm{m})$ & $\mathrm{L}(\mathrm{m})$ & $\mathrm{L}_{1}(\mathrm{~m})$ & $\mathrm{H}_{1}(\mathrm{~m})$ \\
\hline SM1 & HEA500 & HEA450 & 3 & 6 & 0,5 & 0,3 \\
\hline SM2 & HEA500 & HEA450 & 3 & 8 & 0,5 & 0,3 \\
\hline SM3 & HEA500 & HEA450 & 3 & 10 & 0,5 & 0,3 \\
\hline SM4 & HEA500 & HEA550 & 3 & 6 & 0,5 & 0,3 \\
\hline SM5 & HEA500 & HEA550 & 3 & 8 & 0,5 & 0,3 \\
\hline SM6 & HEA500 & HEA550 & 3 & 10 & 0,5 & 0,3 \\
\hline SM7 & HEA500 & HEA700 & 3 & 6 & 0,5 & 0,3 \\
\hline SM8 & HEA500 & HEA700 & 3 & 8 & 0,5 & 0,3 \\
\hline SM9 & HEA500 & HEA700 & 3 & 10 & 0,5 & 0,3 \\
\hline SM10 & HEA500 & IPE450 & 3 & 6 & 0,5 & 0,3 \\
\hline SM11 & HEA500 & IPE450 & 3 & 8 & 0,5 & 0,3 \\
\hline SM12 & HEA500 & IPE450 & 3 & 10 & 0,5 & 0,3 \\
\hline SM13 & HEA500 & IPE550 & 3 & 6 & 0,5 & 0,3 \\
\hline SM14 & HEA500 & IPE550 & 3 & 8 & 0,5 & 0,3 \\
\hline SM15 & HEA500 & IPE550 & 3 & 10 & 0,5 & 0,3 \\
\hline SM16 & HEA500 & IPE750*173 & 3 & 6 & 0,5 & 0,3 \\
\hline SM17 & HEA500 & IPE750*173 & 3 & 8 & 0,5 & 0,3 \\
\hline SM18 & HEA500 & IPE750*173 & 3 & 10 & 0,5 & 0,3 \\
\hline SM19 & HEA500 & IPE750*173 & 3 & 12 & 0,5 & 0,3 \\
\hline SM: SayIsal model & \multicolumn{5}{|l|}{} \\
\hline
\end{tabular}


Kiriş gövdesi gövde eksenine dik doğrultuda L/3 mesafede yüklenmiş olup orta noktasından ise statik artımsal yük ile eğilme etkisine maruz bırakılmıştır. Eğilme etkisi altında hizmet veren, kiriş gövdesine etkiyen yanal yüklerin kiriş taşıma kapasitesine etkisinin incelenmesi amacıyla oluşturan boyutsal değişkenleri verilen bu sayısal modellerin yükleme hali Şekil 5'te verilmiştir.

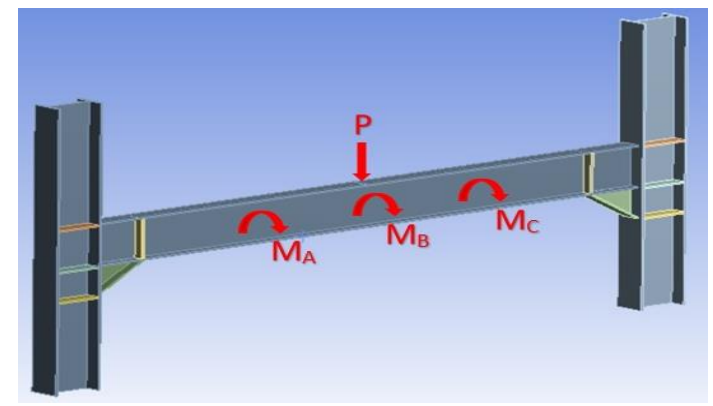

Şekil 5. Sayısal modellere ait yükleme hali

Oluşturulan 19 modelde kirişler orta noktasından statik artımsal yük ile yüklenmiş olup gövdesine dik doğrultuda yanal olarak 11 farklı yük uygulanmıştır. Bu bağlamda toplam 209 analiz yapılmış olup çelik kirişte yanal yükün kapasiteye olan etkisi incelenmiştir. $\mathrm{M}_{\mathrm{A}}+\mathrm{M}_{\mathrm{B}}+\mathrm{M}_{\mathrm{C}}$ şeklinde uygulanan 11 farklı yanal yükün kiriş gövdesinde oluşturduğu moment değerleri Tablo 2'de verilmiştir. Bu verilere ek olarak sayısal modellerin malzeme özellikleri Ansys Work bench sonlu elemanlar programında nonlineer olarak modellenmiştir. Tüm elemanlar solid olarak modellenip her bir elemanın birbirine bağlantısı rijit bağlantı (Bonded) olarak oluşturulmuştur. Kolonların alt ve üst sınır koşulları ise "remote displacement" komutu ile belirlenmiş olup ankastre mesnet koşulları sağlanmıştır. Ayrıca Ansys Workbench programı sonlu eleman yöntemini kullanan bir programı olduğu için sayısal modellerin çözümünde eleman sıklığı önemli faktörlerden biridir. Sayısal modellerin yeterli sayıda elemana bölünmemesi durumunda yük aktarımı başarısız olmakta ve gerçek sonuçtan uzaklaşılmaktadır. Bu nedenle yapılan çalışmada uygun mesh aralığını sağlamak için kiriş açıklığı ve kesiti değerlendirildiğinde $2000-4000$ arasında değişen sayıda eleman seçilmiştir.

Tablo 2. Sayısal modellere $M_{A}+M_{B}+M_{C}$ şeklinde etkiyen yüklerin oluşturduğu burulma moment değerleri

\begin{tabular}{|c|c|c|c|c|c|c|c|c|c|c|c|}
\hline & M1 & M2 & M3 & M4 & M5 & M6 & M7 & M8 & M9 & M10 & M11 \\
\hline $\mathrm{kNm}$ & 0 & 20 & 35 & 45 & 75 & 100 & 140 & 275 & 415 & 560 & 710 \\
\hline
\end{tabular}

\section{BULGULAR VE TARTIŞMA}

Statik artımsal yük altında eğilme etkisine maruz bırakılan çelik bir kirişin taşıma kapasitesine etkisini inceleyebilmek adına kiriş gövdesine dik olarak etkiyen yanal yükler uygulanmıştır.
Bu çalışmada Ansys Workbench sonlu elemanlar programı kullanılarak yapılan sayısal analizlerde mesnet ve şekil etkisi tam ölçekli olarak kurgulanmıştır. Analizlerden elde edilen sonuçları kıyaslayabilmek için kullanılan kiriş kesitlerinin basit kiriş halleri için teorik hesaplamalar yapılmıştır ve elde edilen sayısal değerler Tablo 3'te sunulmuştur.

Tablo 3. Sayısal modellere ait moment kapasiteleri

\begin{tabular}{|c|c|c|c|c|}
\hline KESIT/AÇIKLIK & $6 \mathrm{M}$ & $8 \mathrm{M}$ & $10 \mathrm{M}$ & $12 \mathrm{M}$ \\
\hline \multirow[t]{2}{*}{ HEA450 } & \multicolumn{4}{|c|}{$\mathrm{L}_{\mathrm{r}}=12819,73 \mathrm{~mm}$} \\
\hline & $755,76 \mathrm{kNm}$ & $712,2 \mathrm{kNm}$ & $642,02 \mathrm{kNm}$ & \\
\hline \multirow[t]{2}{*}{ HEA550 } & \multicolumn{4}{|c|}{$\mathrm{L}_{\mathrm{r}}=11893,01 \mathrm{~mm}$} \\
\hline & $1086,17 \mathrm{kNm}$ & $995,65 \mathrm{kNm}$ & $883,58 \mathrm{kNm}$ & \\
\hline \multirow[t]{2}{*}{ HEA700 } & \multicolumn{4}{|c|}{$\mathrm{L}_{\mathrm{r}}=10781,4 \mathrm{~mm}$} \\
\hline & $1646,74 \mathrm{kNm}$ & $1447,48 \mathrm{kNm}$ & $1248,22 \mathrm{kNm}$ & \\
\hline \multirow[t]{2}{*}{ IPE450 } & \multicolumn{4}{|c|}{$L_{r}=6418,18 \mathrm{~mm}$} \\
\hline & $298,27 \mathrm{kNm}$ & $232,44 \mathrm{kNm}$ & $83,64 \mathrm{kNm}$ & \\
\hline \multirow[t]{2}{*}{ IPE550 } & \multicolumn{4}{|c|}{$L_{r}=6788,19 \mathrm{~mm}$} \\
\hline & $543,44 \mathrm{kNm}$ & $278,11 \mathrm{kNm}$ & $178,01 \mathrm{kNm}$ & \\
\hline \multirow[t]{2}{*}{ IPE750*173 } & \multicolumn{4}{|c|}{$\mathrm{L}_{\mathrm{r}}=8163,57 \mathrm{~mm}$} \\
\hline & $1279,32 \mathrm{kNm}$ & $1033,17 \mathrm{kNm}$ & $561,92 \mathrm{kNm}$ & $390,24 \mathrm{kNm}$ \\
\hline
\end{tabular}


Hesaplanan bu moment kapasite değerleri incelendiğinde geniş başlıklı HEA kesitlerinde $L_{r}$ yanal tutulma boyunun hiçbir açıklıkta aşılmadığı, dar başııkı IPE450 ve IPE550 kesitinde $6 \mathrm{~m}$ ve $8 \mathrm{~m}$ açıklıklarda, IPE750*173 kesitinde ise $10 \mathrm{~m}$ ve $12 \mathrm{~m}$ açıklıklarda aşıldığı tespit edilmiştir. Bu bölümde analizlerden elde edilen maksimum kapasite değerleri ve deforme olmuş duruma ait veriler karılaştırmalı olarak sunulmuştur. Bu kapsamda Şekil 6'da analizlerde kullanılan geniş başlıklı profillerin ilk serisi olarak modellenen HEA450 profiline ait artan açıklık ve değişen yanal burulma momenti etkisi altında elde edilen maksimum kapasite eğrileri verilmiştir.

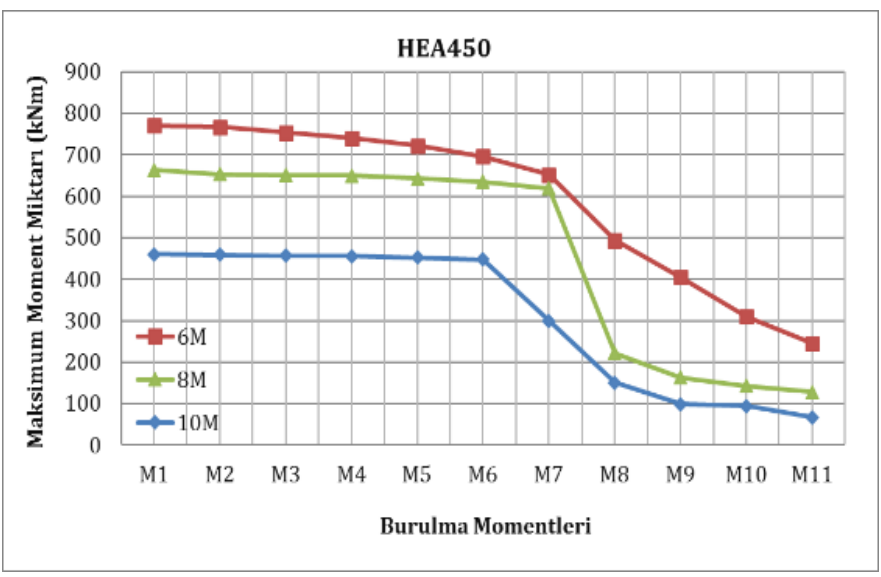

Şekil 6. HEA450 kirişi maksimum kapasite eğrileri

HEA450 profilinin farklı açıklık ve artan yanal yük altında elde edilen maksimum kapasite eğrileri incelendiğinde; yanal yüksüz olarak analizlerde referans kirişi kabul edilen M1 durumu dikkate alındığında yanal yüke bağlı oluşan kapasite kaybının yaşandığı açıkça görülmektedir. Yanal yük altında ortaya çıkan kapasite kayıpları açıklık arttıkça beklendiği üzere daha da belirginleşmektedir.

HEA450 profili için elde edilen dağılımları incelediğimizde $6 \mathrm{~m}$ kiriş açıklığı için moment dağılımlarının orantısal olarak azaldığı, $8 \mathrm{~m}$ ve $10 \mathrm{~m}$ 'lik açıklıklarda ise dağıIımların belli bir burulma momenti değerine kadar düz bir hatta değerler oluşturduğu, $8 \mathrm{~m}$ açıklık için $\mathrm{M7}, 10 \mathrm{~m}$ açıklık için M6 yüklemesinde göçme moduna geçtiği görülmektedir. 8m açıklık için M7 yüklemesine göre 5 katı kadar kapasite değerine, $10 \mathrm{~m}$ 'lik açıklık için ise M6 kritik burkulma yükü dikkate alındığında 4,5 katı kadar kapasite değerine sahip olduğu hesaplanmıştır.

Analizlerde tüm modellerde olduğu gibi HEA450 profilinin artan düşey yer değiştirme ve yanal burulma etkisi altında elde edilen şekil değiştirme dağılımları bu bölüm kapsamında sunulmuştur. Şekil 7'de HEA450 profilinin statik artımsal yük altında ve burulma momentleri etkisinde deforme olmuş durum için elde edilen gerilme dağılımları görülmektedir. Şekillerde analizlerde yanal yük etkisiyle oluşan burulma momentinin davranışa olan etkisini ön plana çıkarabilmek için yüksüz M1 durumu ve kapasite değerlerinde belirgin düşüşler sergileyen $M 7$ ve M8 burulma momenti durumlarına ait görünümler sunulmuştur. Şekil değiştirme dağılımları bu kapsamda incelendiğinde kiriş gövdesi buruşarak deforme olmuş kiriş üst başlığı bu yönde burkulmuştur. $8 \mathrm{~m}$ ve $10 \mathrm{~m}$ açıklığa sahip olan modellerde, açıklığa bağlı deformasyon gövdeden önce başlıkta gerçekleşmiş bu sebeple gövdede buruşma meydana gelmemiştir. 6m'lik açıklık burulma momenti etkisi altında kiriş gövdesi simetri ekseninden burularak deforme olmuştur. Açıklığın arttığı $8 \mathrm{~m}$ ve $10 \mathrm{~m}$ açıklıktaki modellerde mesnet kaynaklı yanal tutulma koşullarının etkisinin azalması kiriş kesitindeki deformasyona da direkt yansımıştır. Burulma etkisinin etkin olduğu M7 ve M8 burulma momentli durumlarda $8 \mathrm{~m}^{\prime}$ 'lik açıklıkta kiriş gövdesi deformasyonu simetri eksenini tam ortalamasa da her iki yönde de deformasyon görülmektedir. Ancak $10 \mathrm{~m}$ 'lik açıklıkta kiriş yanal tutulma rijitliği azaldığı için kiriş ekseni burulma yönünde dışa kaymış kiriş gövdesi bir yönde deformasyona zorlanmıştır. Bu durum teorideki hesaplarda basınç başlığı ve çekme başlığı kabullerinin burulma etkisi kaynaklı değiştiğini ve kiriş kapasitesinin kayba uğradığını açıklamaktadır. 


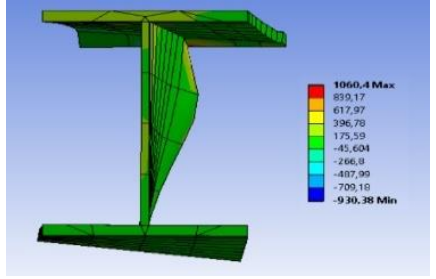

SM1 6m M1 durumu

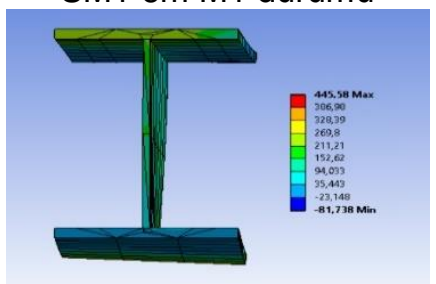

SM2 8m M1 durumu

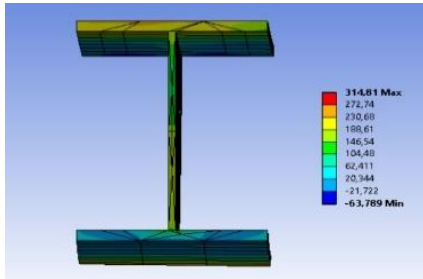

SM3 10m M1 durumu

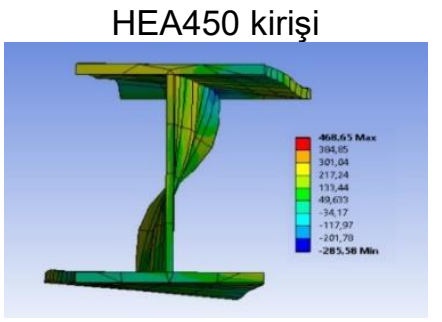

SM1 6m M7 durumu

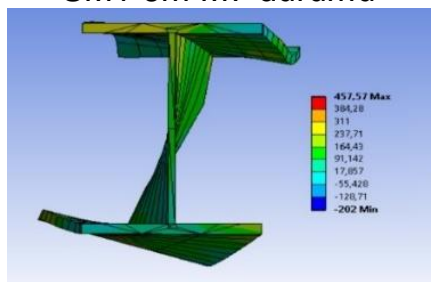

SM2 8m M7 durumu

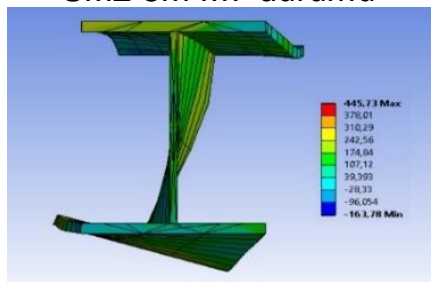

SM3 10m M7 durumu

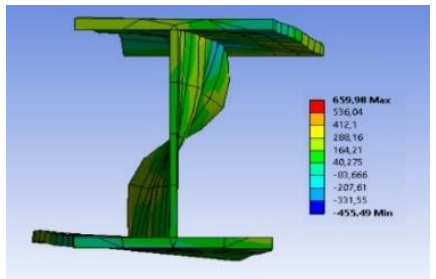

SM1 6m M8 durumu

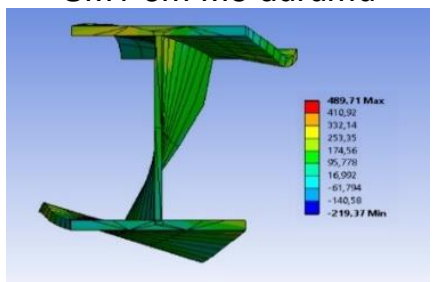

SM2 8m M8 durumu

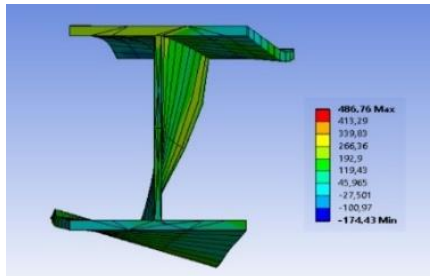

SM3 10m M8 durumu

Şekil 7. HEA450 kirişinin 6,8 ve 10m açıklıktaki şekil değiştirme hallerinin kesit görünümleri

Şekil 8'de verilen HEA550 profilinin yük-deformasyon eğrilerini incelediğimizde HEA450 profiline göre kesit mukavemet değerinin daha rijit olmasından dolayı değerce daha fazla yük taşıma kapasitesine sahip olduğunu görmekteyiz. Fakat bu durum HEA450 profilinde olduğu gibi açıklık arttıkça rijitlik kaybının yaşanmasına engel olamamaktadır. Bu profil için $6 \mathrm{~m}$ ve $8 \mathrm{~m}^{\prime}$ lik açıklıklarda M7 kritik burkulma yüküne kadar orantısal bir azalma olduğu $10 \mathrm{~m}$ 'lik açıklıkta ise M6 kritik burkulma yüküne kadar düz bir hatta ilerlerken bunu takiben göçme moduna geçtiği görülmektedir. HEA550 profili için $8 \mathrm{~m}$ açıklıkta $\mathrm{M} 7$ kritik burkulma yükü referans alındığında 7,1 kat kapasite değerine, 10m açıklıkta M6 kritik burkulma yükü referans alındığında 8,8 kat kapasite değerine sahip olduğu tespit edilmiştir.

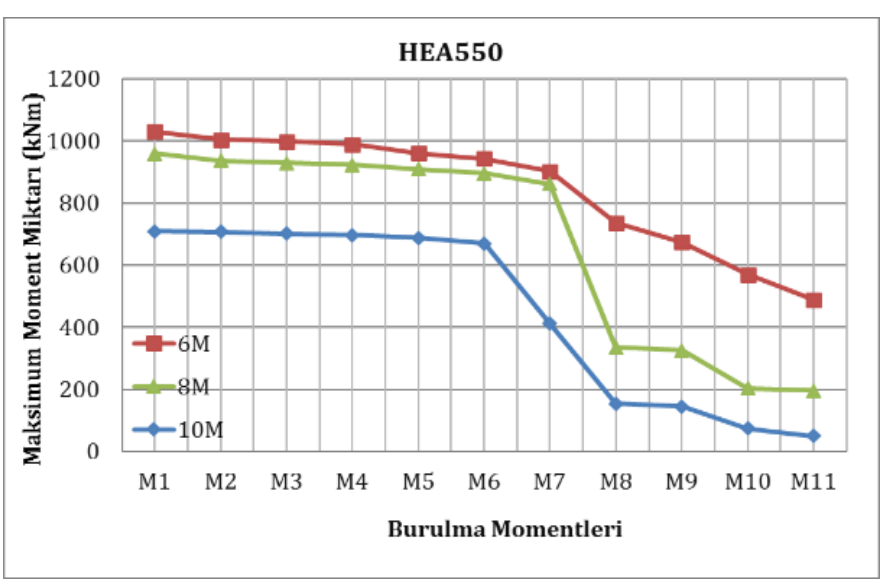

Şekil 8. HEA550 kirişi maksimum kapasite eğrileri 
HEA550 kirişinin şekil değiştirme hallerinin kesit görünümleri Şekil 9'da verilmiştir. Bu kesit görünümleri incelendiğinde HEA450 profiline göre kıyaslandığında kesit mukavemet değerleri daha rijit olmasına rağmen $6 \mathrm{~m}$ açıklığın M1 burulma momentsiz durumunda gövde buruşması davranışından ziyade statik artımsal yük altında basit eğilme davranışı sergilemektedir. $6 \mathrm{~m}$ ve $8 \mathrm{~m}$ açık-
Iıkta M7 ve M8 burulma momentli durumlar değerlendirilmeye alındığında ise mesnetlenmenin verdiği kazanımla gövde yanal ataletine sahip çıkmasının etkisiyle gövdede buruşmalar meydana gelmiştir. 10m açıklıkta ise artık kesit gövdesi açıklığın artmasından dolayı yanal ataletini kaybederek göçme durumuna geldiği için tek yönde burkulma davranışı göstermektedir.

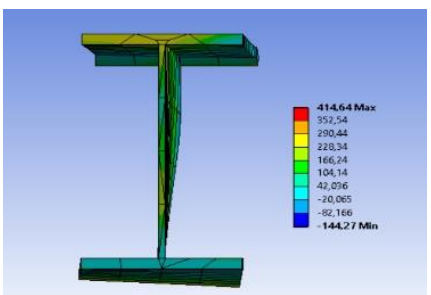

SM4 6m M1 durumu

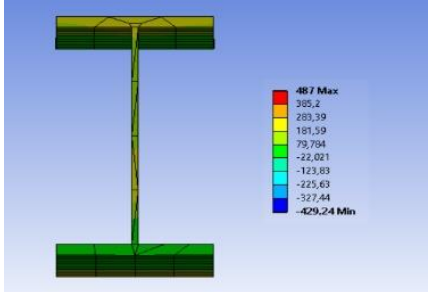

SM5 8m M1 durumu

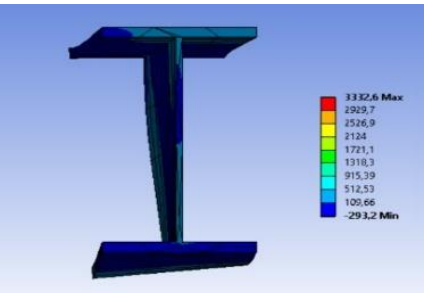

SM6 10m M1 durumu

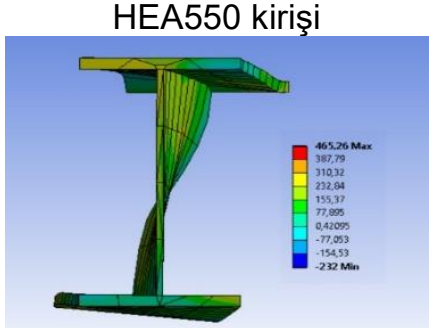

SM4 6m M7 durumu

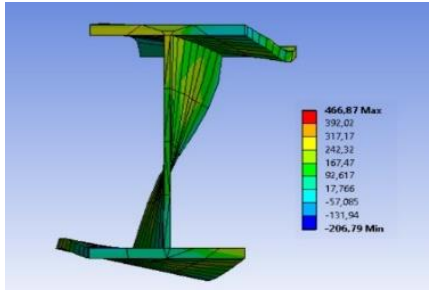

SM5 8m M7 durumu

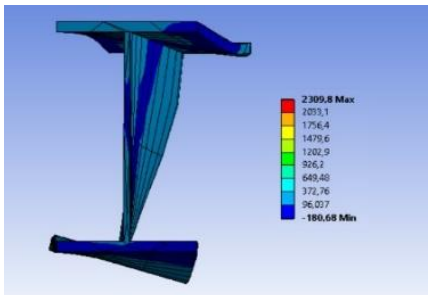

SM6 10m M7 durumu

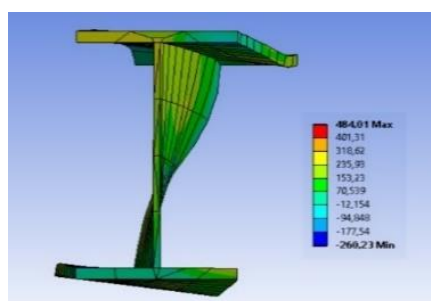

SM4 6m M8 durumu

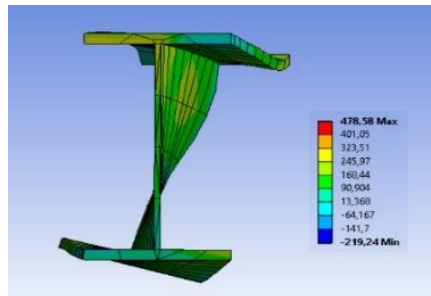

SM5 8m M8 durumu

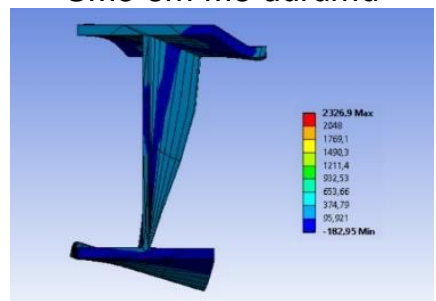

SM6 10m M8 durumu

Şekil 9. HEA550 kirişinin $6 \mathrm{~m}, 8 \mathrm{~m}$ ve $10 \mathrm{~m}$ açıklıktaki şekil değiştirme hallerinin kesit görünümleri

Çalışmada kullanılan son geniş başlıklı HEA700 profili için elde edilen maksimum moment kapasite eğrileri Şekil 10'da verilmiştir. Bu grafik incelendiğinde bu profili içinde $6 \mathrm{~m}$ ve $8 \mathrm{~m}$ açıklık için orantısal bir azalım olduğu görülmektedir. 10m kiriş açıklığı için kritik burulma yükü olan M7 yüküne kadar düz bir hatta sonuçlar elde edilmiştir. Tüm HEA kesitlerinde $6 \mathrm{~m}$ açıklıklarda elde edilen kritik burkulma yükü sonrasındaki moment değerleri incelendiğinde $8 \mathrm{~m}$ ve $10 \mathrm{~m}$ 'lik açıklık dikkate alındığında ani göçme modu görülmemektedir. HEA700 profili M7 kritik burkulma yükü referans kabul edildiğinde $8 \mathrm{~m}$ açıkıı için 10 katı kadar, 10m açıklık için 8,9 katı kadar kapasite değeri elde edilmiştir. 6m'de ise belirgin bir göçme davranışı gözlemlenmemiştir. Aynı durum HEA450 ve HEA550 için geçerlidir. 


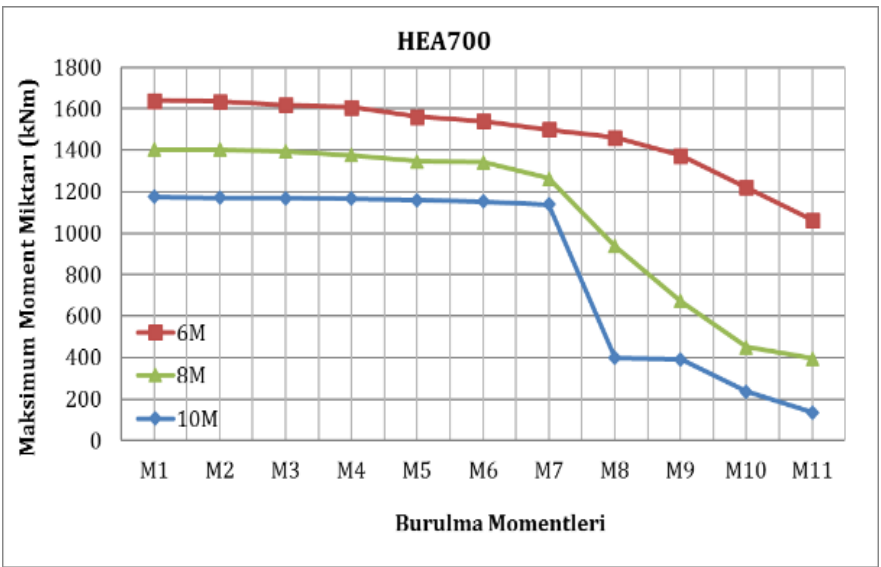

Şekil 10. HEA700 kirişi maksimum kapasite eğrileri

HEA700 profilinin şekil değiştirme dağılımlarının kesit görünümleri Şekil 11 'de sunulmuştur. Bu dağılımlar incelendiğinde referans olarak alınan M1 burulma momentsiz durumda diğer geniş başlıklı profillere göre HEA700 profili kesitçe daha rijit olmasına karşın statik artımsal kuvvet altında sadece başlık ezilmesi değil, gövde yüksekliğinin artmasıyla narinliğe sebebiyet vererek gövde buruşması da başlamıştır. HEA450 ve HEA550 profillerinden farklı olarak sadece $10 \mathrm{~m}$ açıklıkta değil $6 \mathrm{~m}$ ve $8 \mathrm{~m}$ açıklıkta da M7 ve M8 burulma momenti etkisindeyken gövde yanal direnç kaybından kaynaklı tek yönde burkulmaya yönelmiştir.

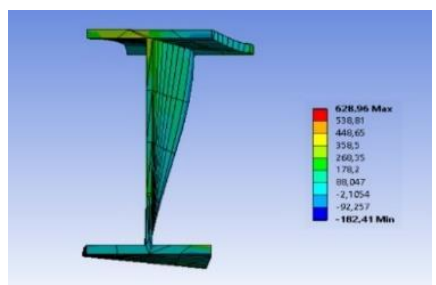

SM7 6m M1 durumu

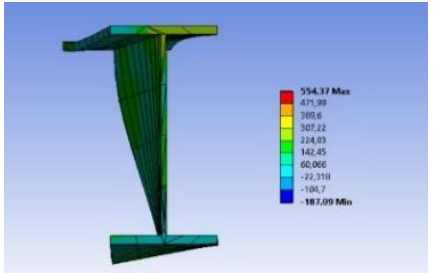

SM8 8m M1 durumu

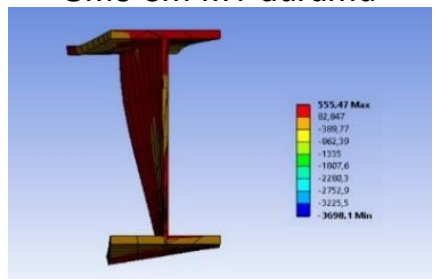

SM9 10m M1 durumu
HEA700 kirişi

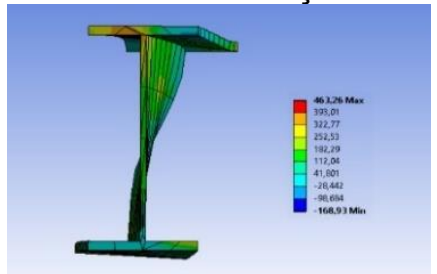

SM7 6m M7 durumu

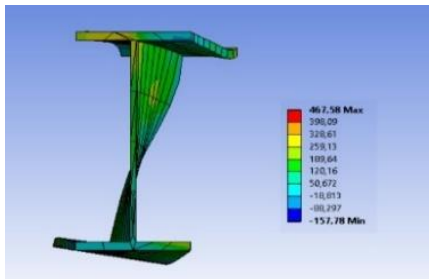

SM8 8m M7 durumu

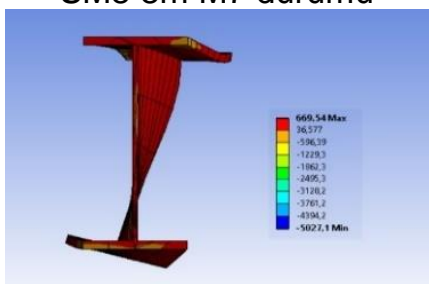

SM9 10m M7 durumu

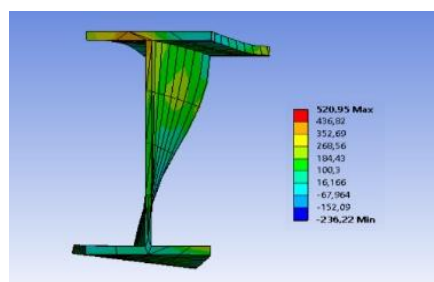

SM7 6m M8 durumu

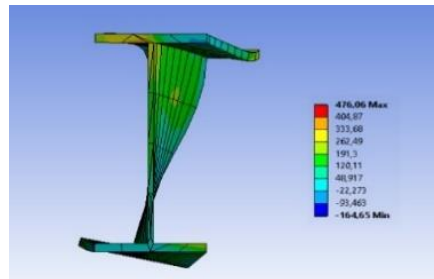

SM8 8m M8 durumu

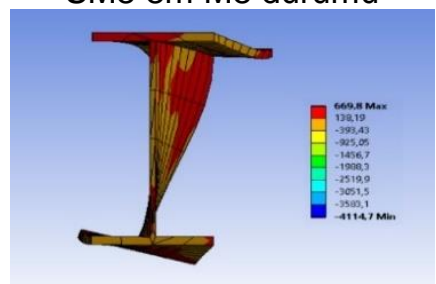

SM9 10m M8 durumu

Şekil 11. HEA700 kirişinin 6,8 ve 10m açıklıktaki şekil değiştirme hallerinin kesit görünümleri

Bu çalışmada yanal burkulmanın kapasiteye etkisini inceleyebilmek ve değerlendirebilmek adına geniş başlıklı HEA kesitlerinin yanında dar başlıklı IPE kesitlerine de yer verilmiştir. İlk olarak Şekil 12'de IPE450 profiline ait olan maksimum moment kapasite eğrileri incelenmiştir. 


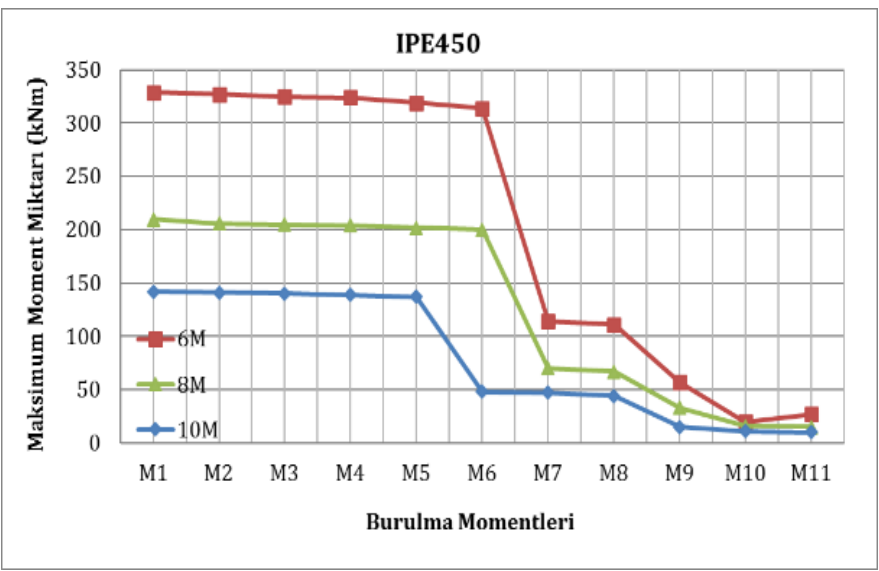

Şekil 12. IPE450 kirişi maksimum kapasite eğrileri

Dar başlıklı profiller için elde edilen moment dağılımları incelendiğinde geniş başlıklara göre davranışça en belirgin farklılık her açıklığın bir öncekine göre yaklaşık maksimum değerce \%20 azalmasıdır. IPE450 için verilen grafik incelendiğinde moment taşıma kapasitesi 6 m'den 8m'ye \%40'lık bir azalım, 8m'den 10m'ye $\% 25$ 'lik bir azalım görülmektedir. Kapasitedeki bu belirgin düşüşler dar başıkkı profilin açıklık arttıkça yanal stabilite problemi yaşamasının bir sonucudur. IPE450 profili $6 \mathrm{~m}$ açıklık için M6 kritik burkulma yüküne kadar orantısal bir azalım sergilerken $8 \mathrm{~m}$ ve $10 \mathrm{~m}$ açıklıklarda sırasıyla M6 ve M5 kritik burkulma yüküne kadar düz bir hatta sonuçlar vermiştir. IPE450 profili $6 \mathrm{~m}$ ve $8 \mathrm{~m}$ açıklık için M6 kritik burkulma yükü referans alındığında kapasitesinin 2,9 ve 2,3 katı kadar kapasite değerine, $10 \mathrm{~m}$ açıklıkta ise M5 yükü referans alındığında 1,1 katı kadar kapasite değerine sahip olduğu görülmüştür. IPE450 profili yanal tutulma üst sınırı olan $\mathrm{Lr}_{r}=6418 \mathrm{~mm}$ 'dir. Yapılan bu hesaplama basit kiriş koşulları için geçerlidir. Mevcuttaki modellemede kiriş kolonlardan tutulu olması sebebiyle yanal destek koşulları basit kirişten ayrışmaktadır. Bu sebeple 8m'lik kiriş açıklığı için hesaplanan M1 yükle- mesi kapasite değeri mesnet koşulları kaynaklı kazanımla $L_{r}$ sınır değerini aşmış olmasına rağmen M6 burulma momenti değerine kadar yük alabilmiş M6 yüklemesiyle birlikte göçme moduna geçmiştir. Aynı durum $10 \mathrm{~m}$ açıklık için de geçerlidir fakat $10 \mathrm{~m}$ açıklıkta ise kiriş M5 yüklemesiyle birlikte göçme moduna geçmiştir.

Şekil 13'te IPE450 kirişinin çalışmada analiz edilen tüm açıklıkları için şekil değiştirme hallerinin kesit görünümleri verilmiştir. Bu şekil değiştirme durumları incelendiğinde $6 \mathrm{~m}$ ve $8 \mathrm{~m}$ açıklıkta yanal yüksüz $\mathrm{M} 1$ durumunda kiriş burulma durumuna geçmeden eğilme davranışı sergilemiştir. 10m kiriş açıklığında mesnet tutulma şartlarının etkisi açıklığa bağlı olarak azaldığı için yanal atalet direncini kaybederek eksen konumunu terk etmeye M1 yüksüz durumdan başlamıştır. M7 ve M8 burulma momentli durumlar incelendiğinde ise HEA kesitli profillere göre dar başlıklı olmasından kaynaklı HEA450 kirişi yanal yüke direnç göstererek gövde buruşması davranışı sergilerken IPE450 profili dar başlıklı olmasında kaynaklı kiriş ekseninden daha fazla sapmıştır. 


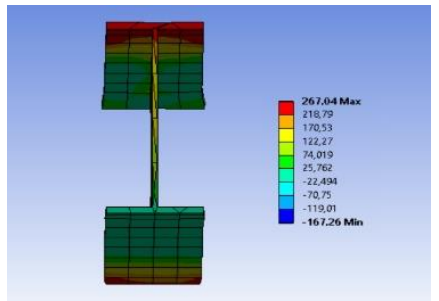

SM10 6m M1 durumu

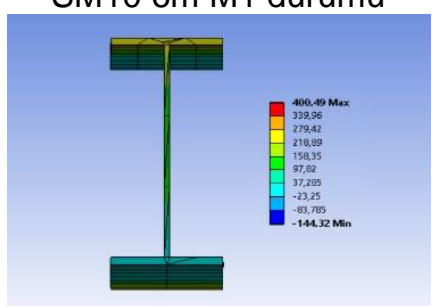

SM11 8m M1 durumu

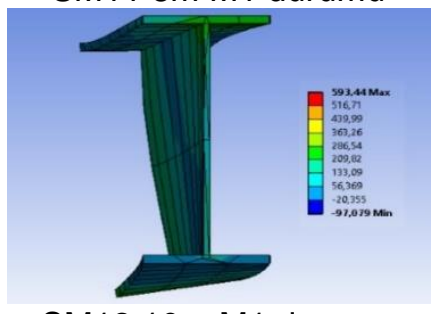

SM12 10m M1 durumu

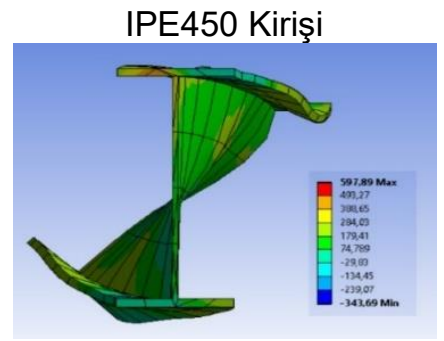

SM10 6m M7 durumu

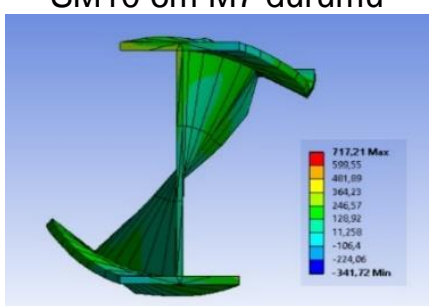

SM11 8m M7 durumu

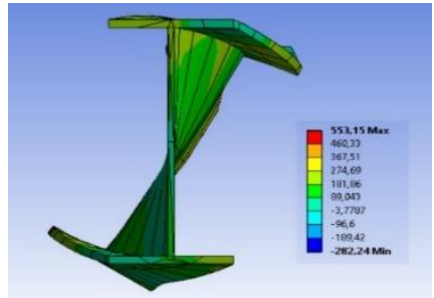

SM12 10m M7 durumu

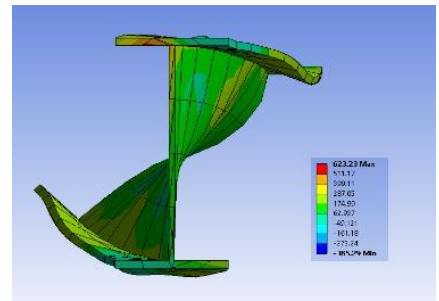

SM10 6m M8 durumu

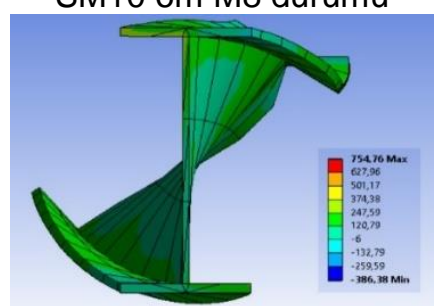

SM11 8m M8 durumu

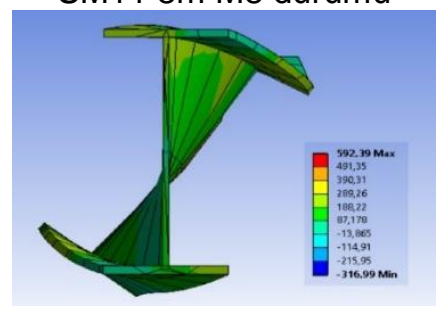

SM12 10m M8 durumu

Şekil 13. IPE450 kirişinin $6 \mathrm{~m}, 8 \mathrm{~m}$ ve $10 \mathrm{~m}$ açıklıktaki şekil değiştirme hallerinin kesit görünümleri

Şekil 14'te IPE550 kirişinin maksimum moment kapasite eğrileri verilmiştir. Bu sonuçlar incelendiğinde $6 \mathrm{~m}$ açıklıkta ilk yanal burkulma yükünün etkidiği $\mathrm{M} 2$ yüklemesi ani bir kapasite kaybına sebep olmuş bunu takiben M5 yüklemesine kadar orantısal bir azalım sergilemiştir. M5 kritik burkulma yükünden sonra ise ani göçme modu gerçeklememiş kiriş kontrollü olarak yük kaybetmiştir. Buna karşın $8 \mathrm{~m}$ ve $10 \mathrm{~m}$ açıklıklarda sırasıyla kritik burkulma yükü olan M5 ve M6'ya kadar doğrusal bir hatta ilerlemiş bu sınır takiben ani göçme moduna geçmiştir. Bu kiriş için yanal burulmasız durum referans alındığında 6m'den 8m'ye geçişte \%40'lık bir kapasite kaybı, $8 \mathrm{~m}$ 'den $10 m^{\prime} y e$ geçişte ise \%33'lük bir kapasite kaybı hesaplanmıştır. Bu bilgilere ek olarak IPE550 kesitinin basit kiriş koşullarında yanal tutulma üst sınırı olan $\mathrm{L}_{r}=6788,19 \mathrm{~mm}$ olarak hesaplanmıştır. Açıklıkça bu sınır IPE450 kesitinde de olduğu gibi $8 \mathrm{~m}$ ve $10 \mathrm{~m}$ 'lik modellerde aşılmaktadır. Fakat bu değerin bu açıklıklarda aşılmasına rağmen $6 \mathrm{~m}$ açıklıktakine benzer davranışlar sergilemiştir.

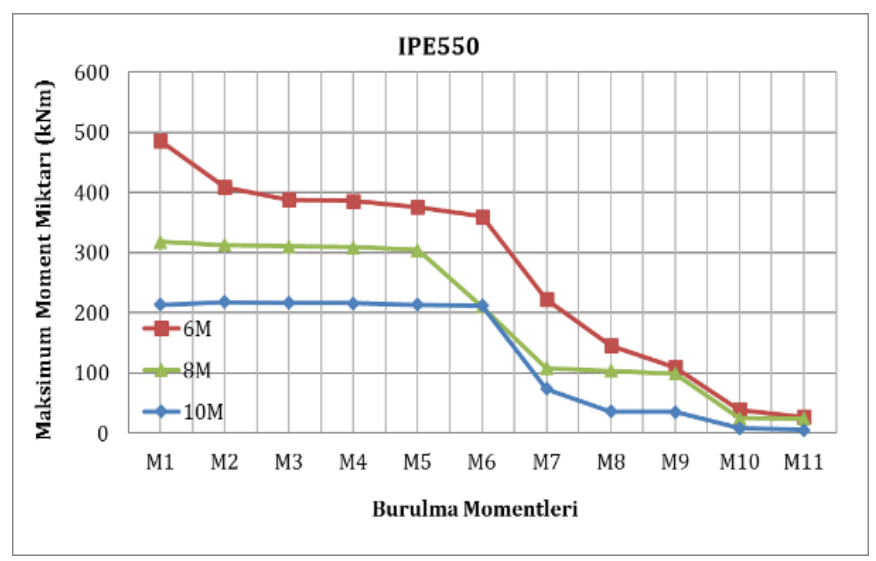

Şekil 14. IPE550 kirişi maksimum kapasite eğrileri 
Şekil 15'te verilen IPE550 kirişinin şekil değiştirme dağılımları incelendiğinde $6 \mathrm{~m}$ ve $8 \mathrm{~m}$ açıklıkta statik artımsal yük altında basit eğilme davranışı gösterirken $10 \mathrm{~m}$ açıklıkta yanal narinlikten dolayı yanal burkulma eğilimindedir ve bu şekil değiştirme dağılımları bu davranışlar eşliğinde IPE450 kirişindeki dağılımlara benzerlik göstermektedir. IPE450 kirişinden davranışça ayrılan yönü ise şu olmuştur; IPE550 kirişi IPE450 kirişine göre kesit ola- rak daha rijit olsa bile IPE kesitler dar başlıklı olmasından kaynaklı gövde yüksekliği IPE550 kirişinde IPE450 kirişine göre fazla olduğu için daha narin davranış sergilemektedir. Bu kapsamda şekillerde görüldügü gibi tüm açıklıklarda M7 ve M8 burulma momentli durumlar incelendiğinde kirişin gövde eksenini terk etmesinde daha büyük farklar ortaya koymuştur.

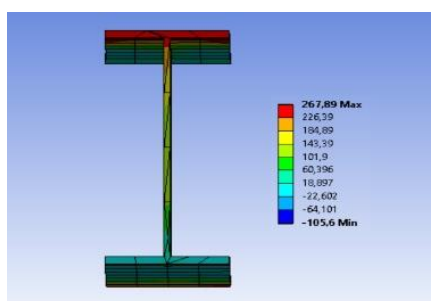

SM13 6m M1 durumu

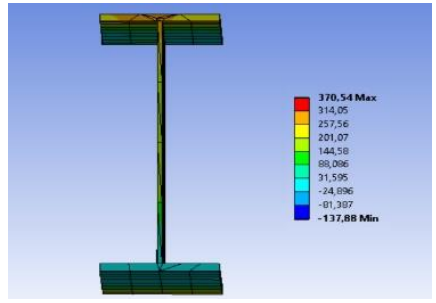

SM14 8m M1 durumu

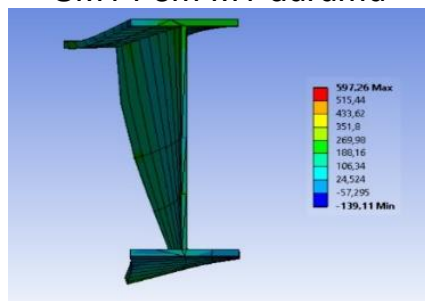

SM15 10m M1 durumu

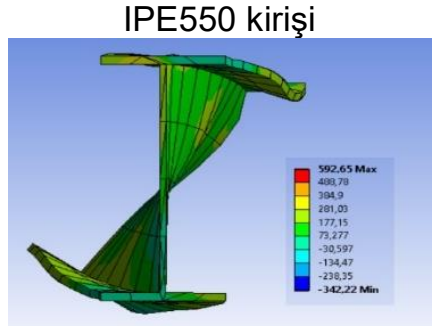

SM13 6m M7 durumu

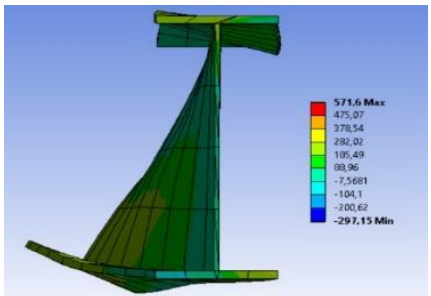

SM14 8m M7 durumu

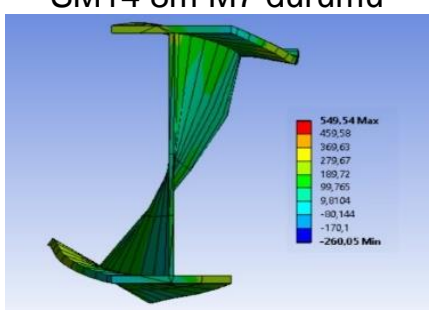

SM15 10m M7 durumu

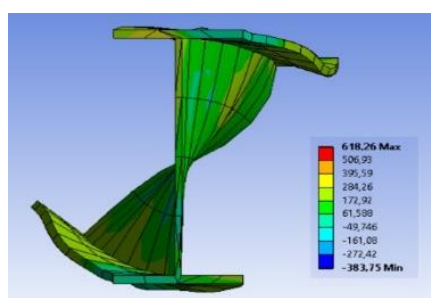

SM13 6m M8 durumu

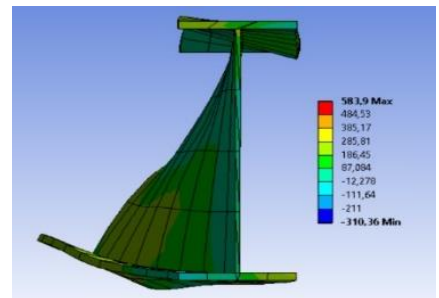

SM14 8m M8 durumu

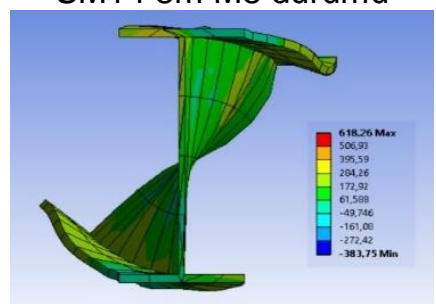

SM15 10m M8 durumu

Şekil 15. IPE550 kirişi $6 \mathrm{~m}, 8 \mathrm{~m}$ ve $10 \mathrm{~m}$ açıklıktaki şekil değiştirme hallerinin kesit görünümleri

Çalışma kapsamında dar başııkı profillerin son sayısal modeli olan IPE750*173 profiline ait sonuçlar diğerlerinden farklı olarak $6 \mathrm{~m}, 8 \mathrm{~m}, 10 \mathrm{~m}$ ve $12 \mathrm{~m}$ 'lik açıklıklar için değerlendirmeye alınmıştır. Şekil 16'da IPE750*173 profilinin farklı açıklıklardaki maksimum moment kapasite eğrileri sunulmuştur. IPE750*173 profili için hesaplanan yanal sınır tutulma koşulu $\mathrm{Lr}_{r}=8163,57$ mm'dir. Bu kapsamda analizlerde bu yanal sınır tutulma koşulu $10 \mathrm{~m}$ ve 12 m'lik açıklıktaki sayısal modeller için aşılmıştır. Ancak kapasite eğrileri incelendiğinde yanal yüksüz ve yanal yüklü durumlara ait kapasite değerleri ve davranışları göstermektedir ki $10 \mathrm{~m}$ ve $12 \mathrm{~m}$ 'lik açıklıkta dahi yanal tutulma boyu olan $L_{r}$ değerinin aşılmadığı $8 m^{\prime}$ 'lik modele benzer davranışlar elde edilmiştir. Buradan anlaşıldığı üzere mesnet tutulma koşulları kirişin yanal ötelenme rijitliğini ve tutulma koşullarını etkilemektedir. Kapasite eğrileri, analiz edilen açıklıklar kapsamında değerlendirildiğinde $6 \mathrm{~m}$ ve $8 \mathrm{~m}$ açıklığa sahip moment kapasite eğrilerinde olduğu gibi $M 7$ kritik burkulma yüküne kadar düz bir hatta değerler almıştır. Bu profile ait tüm açıklıklarda M7 kritik burkulma yükünü takiben ani göçme modu gerçekleşmiştir. IPE750*173 profilinde $6 \mathrm{~m}$ 'den $8 m$ 'ye geçişte $\% 25$, 8m'den 10m'ye geçişte \%30, 10 m'den 12 m'ye geçişte ise \%25 kapasite kaybı oluşmuştur.

Şekil 17.'de verilen IPE750*173 profillerinin şekil değiştirme dağılımlarında ilk olarak yanal yüksüz M1 durumu incelendiğinde $6 \mathrm{~m}$ açıklıkta önce kiriş gövdesi buruşup üst başlık bu yönde burkulurken $8 \mathrm{~m}, 10 \mathrm{~m}$ ve $12 \mathrm{~m}$ 'lik açıklıklarda ise deformasyon gövdeden önce başlıkta 
meydana gelmiştir. M7 ve M8 burulma momentleri incelendiğinde ise belirgin yanal burkulma davranışları gözlemlenmektedir.

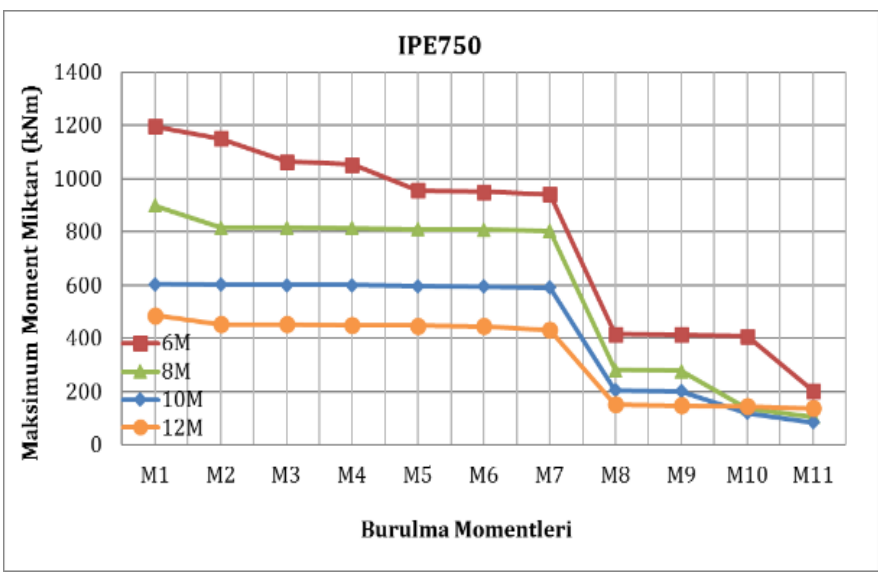

Şekil 16. IPE750*173 kirişi maksimum kapasite eğrileri

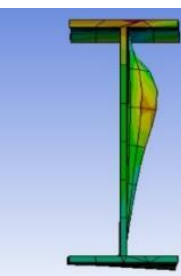

SM16 6m M1 durumu

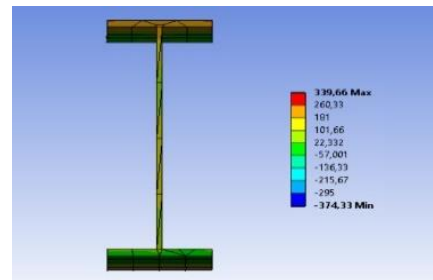

SM17 8m M1 durumu

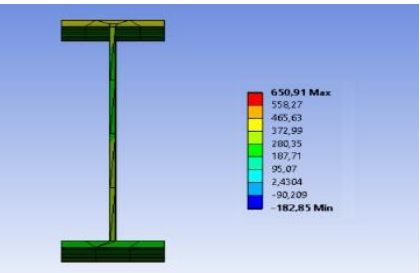

SM18 10m M1 durumu

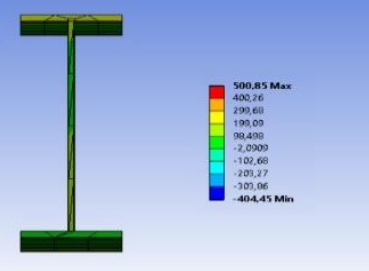

SM19 12m M1 durumu

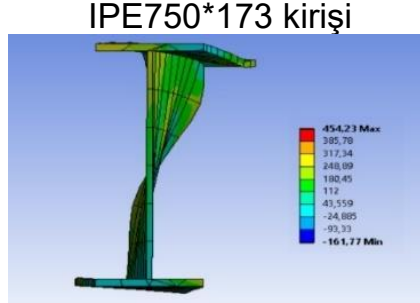

SM16 6m M7 durumu

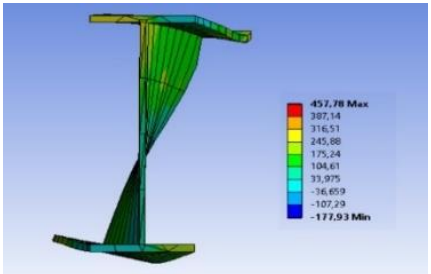

SM17 8m M7 durumu

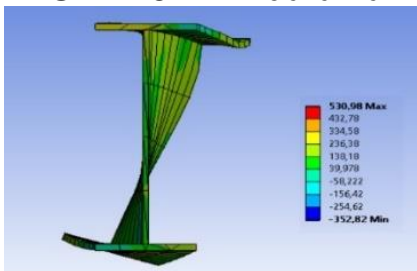

SM18 10m M7 durumu

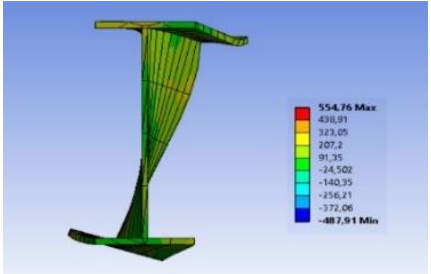

SM19 12m M7 durumu

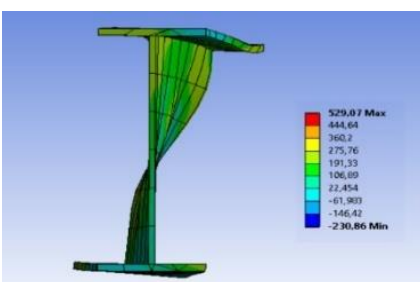

SM16 6m M8 durumu

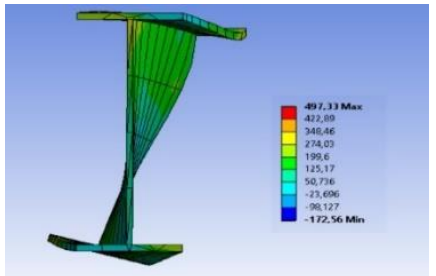

SM17 8m M8 durumu

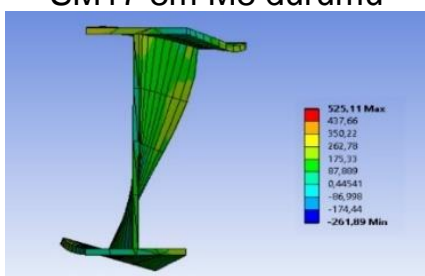

SM18 10m M8 durumu

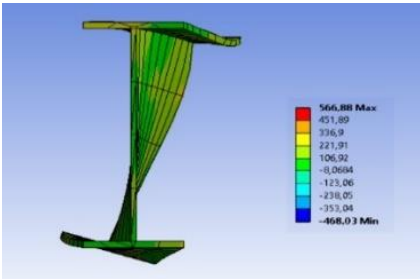

SM19 12m M8 durumu

Şekil 17. IPE750*173 kirişi $6 \mathrm{~m}, 8 \mathrm{~m}$ ve $10 \mathrm{~m}$ açıklıktaki şekil değiştirme hallerinin kesit görünümleri 


\section{SONUÇLAR}

Ansys Workbench sonlu elemanlar programı kullanılarak yapılan analizlerde tüm modellerin statik artımsal yük altında artarak etkiyen yanal yükle birlikte, yanal doğrultuda üst başlıktan başlayarak burkulduğu görülmüştür. Analiz edilen tüm modellerin kapasite-moment eğrileri incelendiğinde kiriş kesiti büyüdükçe taşıma kapasitesinin arttığı fakat yanal yükün devreye girmesiyle kapasitede kayıp yaşandığı görülmüştür. Her bir kiriş kesiti ayrı olarak kendi içlerinde karşılaştırıldığında ise açıklık arttıkça kapasite kaybının yaşandığı daha belirgin bir hal almıştır.

Sayısal olarak yapılan bu çalışmada eğilme etkisi altındaki bir kirişte, kirişe eklenen yanal yüklerin oluşturduğu burulma momentlerinin yapısal davranışa ve kapasiteye etkisi incelenmiştir. Sayısal çalışma dar başlıklı ve geniş başlıklı olmak üzere kesit olarak iki farklı grup oluşturulmuştur. Oluşturulan sayısal modellerde kirişlerin sınır koşullarını bir çerçeve sistem içerisinde çalıştığı kabulü üzerinden yapılarak belirlenmiştir. Bu kapsamda tüm modellerde kirişler her iki uçtan HEA500 profillerine moment aktaracak şekilde mesnetlenmiştir. Kullanılan kiriş açıklıkları $6 \mathrm{~m}, 8 \mathrm{~m}, 10 \mathrm{~m}$ ve $12 \mathrm{~m}$ olarak ele alınmıştır. Sayısal modeller geniş başlıklı profiller HEA450, HEA550 ve HEA700 profilleri kullanılarak oluşturulmuştur. Dar başlıklı profiller ise IPE450, IPE550 ve IPE750*173 olarak seçilmiştir. Statik artımsal olarak etkiyen düşey yük altında analiz edilen tüm modeller yanal yüklü ve yanal yüksüz olarak irdelenmiştir. Yanal yüksüz olarak analiz edilen modeller referans kabul edilmiş ve 10 farklı yanal yük kombinasyonu için elde edilen sonuçlar ile karşılaştırılmıştır.

Eğilme etkisiyle birlikte artarak uygulanan yanal yüklerin oluşturduğu burulma momentleri kirişin kapasitesini düşürmüştür. Ancak burulma momentlerinin kapasiteye olan yansıması dar başlıklı ve geniş başlıklı profillerde davranışça farklılık göstermiştir. Geniş başlıklı tüm profillerde burulma momenti kaynaklı kapasite kaybı tüm açıklıklar için M7 burulma momentli duruma kadar orantısal bir düşüş sergilemiş, bunu takiben yanal burulma etkileri altında göçme durumuna geçmiştir. Dar başlıkı tüm profillerin tüm açıklıklarında ise ilk yanal yüklemede belirgin bir eğimle bir kapasite kaybı tespit edilmiş ve buna müteakip orantısal düşüşler sergilenmiştir. Bu modellerde de M7 yüklemesi kritik eşik olup kirişlerin göçme moduna geçmesinde belirleyici olmuştur.

Çalışmada statik artımsal yük ve artan yanal yükler altında deformasyona bağlı oluşan gerilme-şekil değiştirme dağılımları incelendiğinde; burulma momentinin yanal ötelenme rijitliğini aşamadığı tüm modellerde şekil değiştirmenin başlık burkulması (basınç başlığı) veya gövde buruşması şeklinde sonuçlandığı tespit edilmiştir. $\mathrm{Bu}$ durum tüm kirişlerde $\mathrm{L}_{r}$ yanal tutulma boyunun altında kalan açıklıklarda elde edilmiştir. Yapılan analizlerde $6 \mathrm{~m}^{\prime}$ 'lik açıklıklar için tüm profillerde bu davranış gözlemlenmiştir. Açıklık arttığında yanal yük devreye girmediği durumlarda deformasyonun üst başlık burkulması şekliyle gerçekleştiği, yanal yük devreye girdiği durumlarda ise profillerin yanal burkulma davranışına geçtiği gözlemlenmiştir.

Sayısal olarak yapılan bu çalışmada kullanılan tüm profiller için yanal tutulma boyları hesaplanmıştır. Bu kapsamda geniş başlıklı profillerde analiz yapılan açıklıklar için yanal tutulma sınır koşulu aşılmamıştır. Dar başlıklı profillerde ise IPE450 ve IPE550 profilinde $8 \mathrm{~m}$ ve $10 \mathrm{~m}$, IPE750*173 profilinde ise $10 \mathrm{~m}$ ve $12 \mathrm{~m}$ kiriş açıklıklarında yanal tutulma sınır koşulu aşıımıştır. Kapasite eğrileri incelendiğinde yanal rijitliğin kaybolduğu modellerde yanal yüksüz ve yanal yüklü ilk yükleme değerlerinin kapasite ve davranışça benzer olduğu görülmektedir. Ancak IPE450 profili 8m açıklık, IPE550 profili 8m ve $10 \mathrm{~m}$ açıklık, IPE750*173 profili $10 \mathrm{~m}$ ve $12 \mathrm{~m}$ kiriş açıklıkları için elde edilen davranışlar incelendiğinde tutulma koşulları aşılmış olmasına rağmen $\mathrm{M} 1$ yüklemesinin burulma momentli oluşturan yüklemelerden ayrıştığı açıkça görülmektedir.

Sonuç olarak yapılan analizler neticesinde eğilme etkisi altında olan bir kirişte artarak etkiyen yanal yüklerin oluşturduğu burulma momentinin kiriş kapasitesi ve davranışında belirleyici olduğu, geniş başlıklı profillerin dar başlıklı profillere göre sahip olduğu kesit özelliklerinin bir sonucu olarak yanal rijitliğinin büyük olduğu görülmüştür. Moment taşıma kapasiteleri incelendiğinde geniş başlıklı profillerde yanal yüksüz durum referans alındığında moment kapasitesinin açıklık artışından çok etkilenmediği, dar başlıklı profillerde ise her iki metrelik açıklık artışında ortalama \%30 kapasite kaybının meydana geldiği görülmüştür. Yanal yüklü durumlarda ise geniş başlıklı profillerin $L_{r}$ tutulma boyu sınırları dahilinde kritik burkulma yükü sonrasında ani kapasite kaybına uğramadığına kritik burkulma öncesinde de orantısal azalan kapasite kayıpları sergilediği görülmüştür. Buna karşın dar başlıklı profillerde kritik burkulma yükü sonrası ani göçme modunun gerçekleştiği burkulma yükü öncesinde ise açıklıkla değişen davranışlar sergilediği tespit edilmiştir. Elde edilen sonuçlar ışığında eğilme etkisi altında yanal yüklerle birlikte etki eden eğilme etkisi altındaki bir kirişte kesit özelliklerinin kiriş yanal tutulma boyunun belirleyici olduğu tespit edilmiştir. 


\section{KAYNAKLAR}

Anapayan, T., Mahendran, M., Mahaarachchi, D. (2011). Lateral distortional buckling tests of a new hollow flange channel beam. Thin-Walled Structures, 49(1): 13-25.

Attard, M. M. (1986). Lateral buckling analysis of beams by the fem. Computers \& Structures, 23(2): 217-231.

Ayhan, D. (2007). Çelik Kirişlerde Yanal Burulmalı Burkulma Analizi. İstanbul: İstanbul Teknik Üniversitesi Fen Bilimleri Enstitüsü.

Elgaaly, M., Seshadri, A. (1998). Depicting the behavior of girders with corrugated webs up to failure using non-linear finite element analysis. Advances in Engineering Software, 29(3-6): 195-208.

Ellobody, E. (2011). Interaction of buckling modes in castellated steel beams. Journal of Constructional Steel Research, 67(5): 814-825.

Lee, J., Kim, S.-E., Hong, K. (2002). Lateral buckling of I-section composite beams. Engineering Structures, 24(7): 955964.
Mahendran, M., Avery, P. (1996). Buckling Experiments on Hollow Flange Beams with Web Stiffeners. Journal of Structural Engineering, 123(9): 1130-1134.

Moon, J., Yi, J.-W., Choi, B. H., Lee, H.-E. (2009). Lateral-torsional buckling of I-girder with corrugated webs under uniform bending. Thin-Walled Structures, 47(1): 21-30.

Mudenda, K., Zingoni, A. (2018). Lateral-torsional buckling behavior of hot-rolled steel beams with flange upstands. Journal of Constructional Steel Research,144: 53-64.

Trahair, N. (2016). Torsion Equations for Lateral Buckling. Engineering Structures, 128: 161-165.

Tsavdaridis, K. D., D'Mello, C. (2011). Web buckling study of the behaviour and strength of perforated steel beams with different novel web opening shapes. Journal of Constructional Steel Research, 67(10): 1605-1620.

Yılmaz, T., Kıraç, N. (2016). On the Evaluation of Critical Lateral-Torsional Buckling of Monosymmetric Beam-Columns. World Academy of Science. Engineering and Tecnology International Journal of Civil and Environmental Engineering, 10(7): 885-892. 